\title{
A New Method of Photographing Air Current.
}

\author{
By Kyoji Suyehiro, Member.
}

\begin{abstract}
.
In this method fine charcoal powder made from hemp reed is fed into air the flow of which is to be studied. At the inlet a small ignition tube is fitted through which the powder being kindled is passed into the current of air. Thus the flow of air is made visible to the eye or sensible to photographic plates.
\end{abstract}

In aerodynamical investigations Töpler's or Dvorak's method of photographing air current is often used for the observation of the flow of air." ${ }^{1)}$ No doubt these methods are satisfactory for exploring every detail of the motion of air, and there is nothing to be desired; yet owing to the complicacy of these methods, a simpler one may not be undesirable for those cases where merely the general nature of the flow is the object of study. For such a purpose observations are not soldom made by feeding smokes or introducing dusts into air. But such a method is not fruitful when the speed of the air current is pretty high.

The method which was devised by the auther is no other than that of suspended dusts. But in his method "dusts" are ignited to make their tracks impressive to the eye or sensitive to photographic plates. Instead of introducing cold "dusts" into air as is usually done, the fine powder of a light and combustible substance is fed into the air current on the back of the equalizer of a wind channel through an ignition tube electrically heated in which the powder takes fire before entering into the current. Among various substances which have so far been tried for thin purpose, fine charcoal powder made from hemp reed (cannabis sativa) gave the best result.

1) A. Tanakadate, Compte Rendus, Juillet, 1910. K. Terazawa, Rep. Aero. Res. Insti. Vol. I, 8. 
Figs. 1-4 show the flow of air past different obstacles as revealed by the present method using this charcoal powder. The flow of air past an inclined straight plate $(6 \mathrm{~cm}$. wide) is shown in Fig. 1, and the same past an electric fan blade (about the same width) in Fig. 2. In both cases the speed of the air current was nearly $210 \mathrm{~m}$. per min. In Figs. 3 and 4 is shown the same past circular cylinders of $2.6 \mathrm{~cm}$. in diameter with a speed of nearly $330 \mathrm{~m}$. per min. The cylinder shown in Fig. 4 had small projections on the sides along the generating line, while that shown in Fig. 3 was plain. The photographs show that the flow is influenced by the presence of the small projections, the area of the eddy wake being diminished by their action. In all cases the powder used was sifted by a sieve having a guaze of 400 meshes per sq. $\mathrm{cm}$.

It will be seen that the powder pretty well follows the motion of air, though it fails to show every detail of the motion, such as the chaos on the wake. The use of the charcoal powder, however, has a drawback in that, as the colour of the light given out by its ignition is feeble and red, it is not very sensitive to ordinary photographic plates.

Alminium powder was also tried, as it gives out a strong white light while it burns and does not scintillate. When it is very fine and mixed with a proper amount. of noncombustible powder to retard quick burning, it may be a suitable material for obtaining a clear photograph of the tracks of the particles. Its heaviness, however, seems to be objectionable, if not prohibitive, to use this material for the present purpose. When burning alminium powder is used, the photograph of air current past an inclined plane appears as shown in Fig. 5. Although in taking this photograph the finest powder obtainable was used, yet it does not show the real picture of the air current.

The author wishes to express his thanks to Messrs. Awada and Tanaka of the Mitsubishi Laboratory for their faithful assistance in carrying out the present experiment. 
Fig. 1.

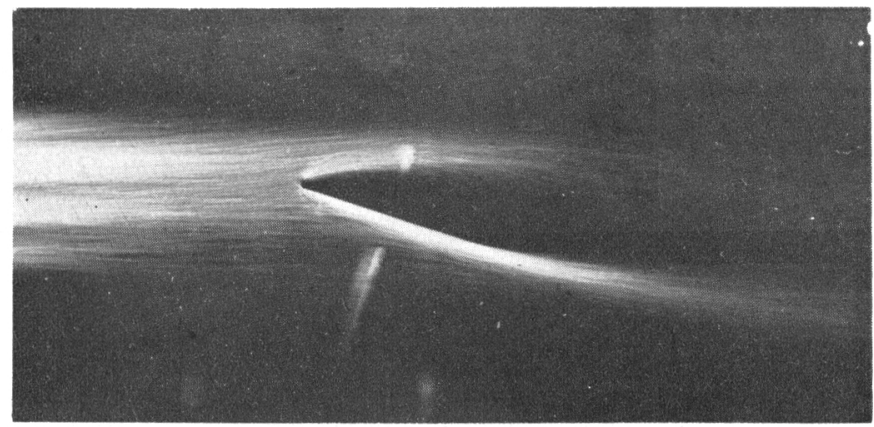

Fig. 2

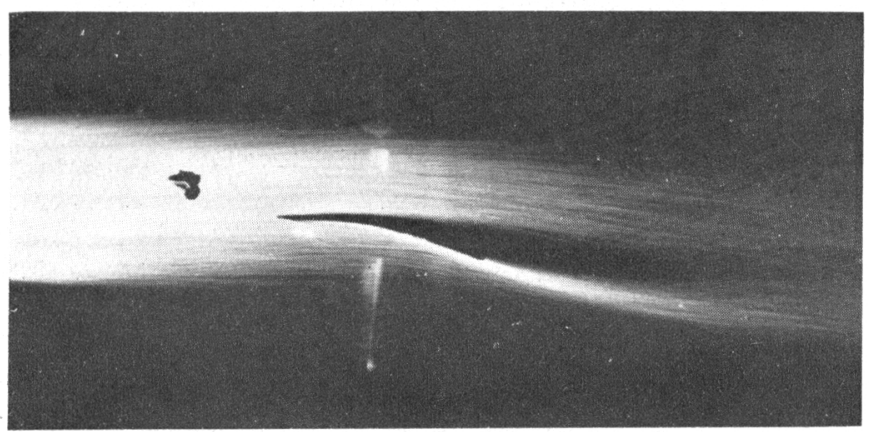

Fig. 3.

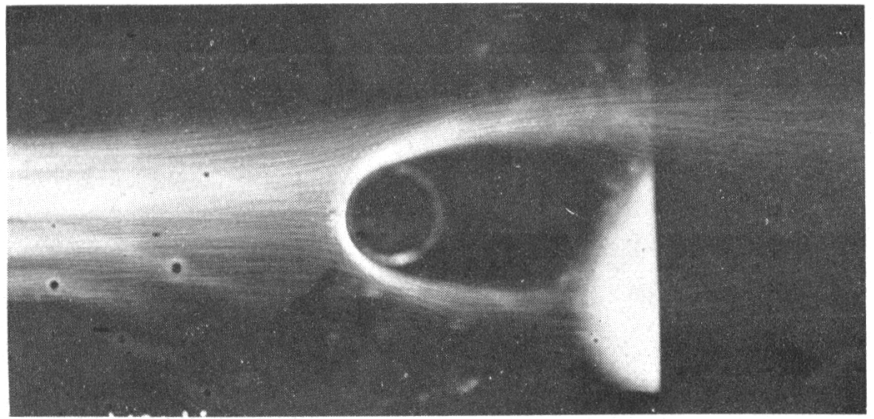

Fig. 4

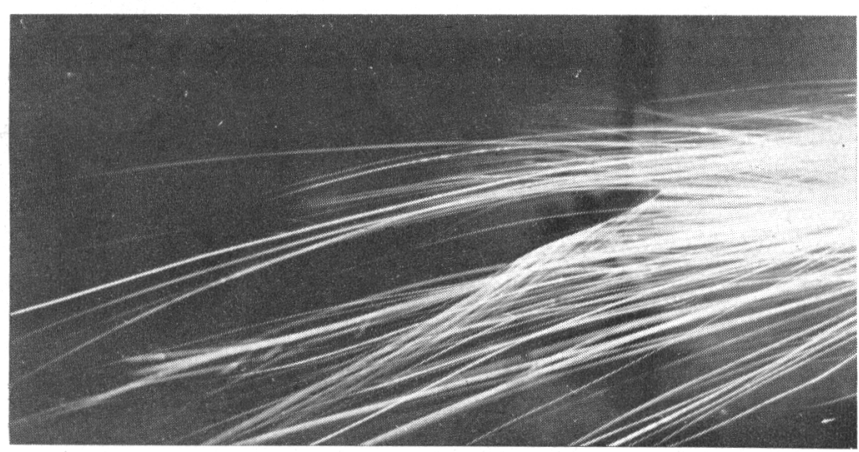

Fig. 5.

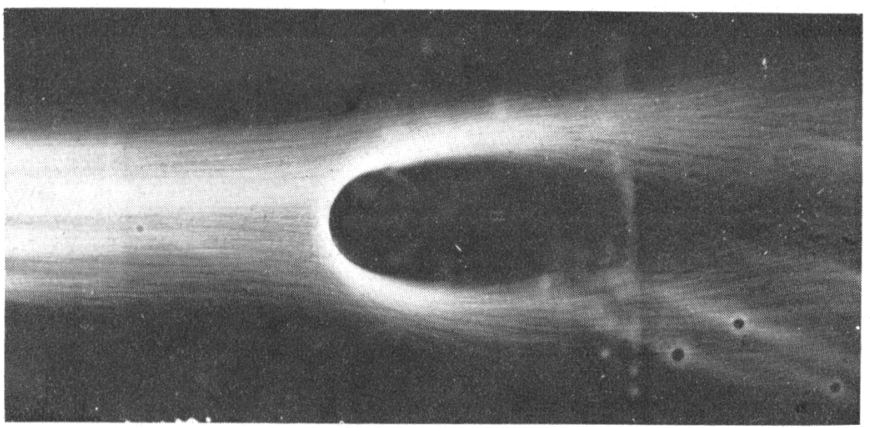




\section{討論}

○會長（今岡純一郎君） 御質問なり御討論なりありますれば……。

○橋本賢輔君 其「パウダー」が表面に着きませ妨、面は綺麗でありますか。

○末廣恭二君「パウダー」は殆んど着きませぬ、しかし念の爲め一實驗每に布で拭取つて居りま 广。

○橋本賢輔君 もつと短い「エキスポージュア」の寫真はありませぬか。

○末廣恭二君 もつと短時閌のは中々寫りませ奻「スペシアルラピッド」を「アンモニア」で「セ ンシタイズ」してやつて見ましたが、矢張り好結果を得ません。「ステッディー、フロー」を寫すのには 時間が掛かつてもかまいませんから二十秒乃至三十秒位「エキスポーズ」してやつて居ります。夫か ら此實驗の缺點は實驗室が䃭なくなつてたまらない。併し今は「サクション」で室外へ出して任舞ふ 方法を講じてねます。

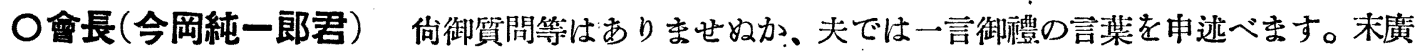
博士は常に御研究に没頭せられで居りまして、有益なる御研究を絕えず本會に御發表になつて居りま すが、今日又斯樣な斬新なる方法を吾くに御示しになりました。向只今の御言葉では御病氣の爲に一。 層完成するてとが出來なかつたと云ふてとでありますが、何卒今後も御研究になりまして、次包なり 其次すまでには御發表下さるゃらに、令から諸君と共に御願ひ致して䈯きたいと思ひます。拍手を 以て末廣博士の御請演に對して御禮を申上げます。 